ISSN 1984-3755

Licenciado sob uma Licença Creative Commons

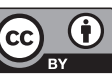

\title{
A oração desde 0 ser: ontologia da vida orante
}

\author{
Prayer from being: ontology of life prayerful
}

\author{
Jacir Silvio Sanson Junior, Marcelo Martins Barreira*
}

Universidade Federal do Espírito Santo (UFES), Vitória, ES, Brasil

\section{Resumo}

Para ser concebida de maneira integral, é preciso endereçar uma crítica a regimes disciplinares que involucram a vida de oração a estratos de controle exteriores. Explorando uma intersecção entre Teologia Espiritual e Ontologia, correlacionamos as formas de oração, discriminadas por antigas fontes cristãs e o Catecismo da Igreja Católica, com as propriedades transcendentais do ser, segundo Regis Jolivet. Abre-se a perspectiva de uma ligação mais essencial da oração com o suposto natural das faculdades humanas, já não mais com um agir ético heterônomo ou uma deontologia dos costumes.

Palavras-chave: Ser. Transcendentais. Formas de oração.

\section{Abstract}

To be conceived fully, we must address a critical to disciplinary regimes that involves the prayer life to stratus of externals control. Exploring an intersection between Spiritual

* JSSJ: Mestrando em Filosofia, e-mail: jasisaju@hotmail.com

MMB: Pós doutorado, e-mail: marcelobarreira@ymail.com

Rev. Pistis Prax., Teol. Pastor., Curitiba, v. 8, n. 2, 445-464, maio/ago. 2016 
Theology and Ontology, it correlates forms of prayer, broken down by ancient Christian sources and the Catechism of the Catholic Church, with the transcendental properties of being, according Regis Jolivet. Opens up the prospect of a more fundamental connection of prayer with the supposed natural human faculties, no longer with a heteronomous ethical action, as little with deontological mores.

Keywords: Being. Transcendental. Forms of prayer.

\section{Introdução}

Em atenção às páginas neotestamentárias, o Catecismo da Igreja Católica (CAT) apresenta os cinco tipos de oração: (i) bênção e adoração, (ii) petição, (iii) intercessão, (iv) ação de graças e (v) louvor ${ }^{1}$. Acreditamos não estar diante de um dado descritivo apenas, mas de uma compreensão modelar: são tão somente as formas da oração, tais como reveladas nas Escrituras apostólicas canônicas, que recebem propriamente um aspecto de normatividade em matéria de espiritualidade cristã (cf. CAT § 2625) ${ }^{2}$.

Empregando as definições trazidas pelo Catecismo, debateremos suas imbricações com alguns elementos de Ontologia, os princípios transcendentais do ser, tendo à frente a referência de Régis Jolivet (1982) em seu Curso de Filosofia. Essa correspondência promove o entendimento de que a norma da oração só tem autenticidade ontológica e, por isso, não é conveniente sobrepor determinações disciplinares à prática oracional.

1 "Adoração e louvor, confissão, ação de graças, súplica e intercessão (oração pelos outros)" é como Arnaldo Schüler (2002, p. 340) mostra em sua semelhante listagem. As epístolas paulinas, ao menos em dois momentos, fazem explícita menção: em Fl 4, 6 - "Nada vos preocupe. Pelo contrário, em vossas orações

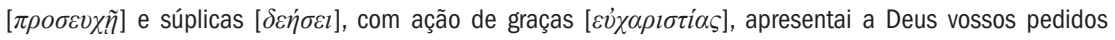

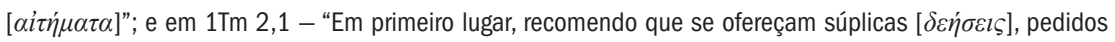

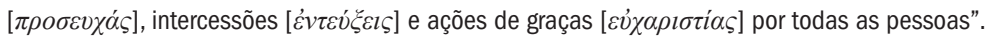

2 A Instrução sobre as orações para alcançar de Deus a cura, da Congregação para a Doutrina da Fé, é outro documento normativo do Magistério eclesiástico sobre a oração. Nele são emitidas várias disposições disciplinares sobre a oração de cura.

Rev. Pistis Prax., Teol. Pastor., Curitiba, v. 8, n. 2, 445-464, maio/ago. 2016 


\section{Problematização: a oração como dever e/ou espontaneidade}

O exercício da oração é comumente destacado pela comunidade confessional como uma ação vital, sem a qual a alma, desconectada das fontes sobrenaturais, fatalmente desfaleceria. Um exemplo está no clássico tratado Compêndio de Teologia Ascética e Mística, de Adolfo Tanquerey (1955 [1928], n. 507-508), onde reflete que a exigência moral de orar está embasada na necessidade natural e espiritual do homem pela liberalidade divina.

Tradições espirituais bastante experimentadas na prática e na doutrina transmitem e reiteram a convicção de que um ato de fé, pelo qual uma pessoa singulariza sua adesão a um referencial transcendente, precisa ser abastecido pela oração atenta e constante. Assiste-se que a importância desse expoente não possa ser deixada ao ímpeto da espontaneidade.

Esse retrato contraria, no entanto, o propósito de uma vida orante articulada com a promoção do ser. Postularemos, a título de princípio, que a disciplinarização da oração a parâmetros sócioinstitucionais tende a corromper uma terapêutica sempre em voga: ao invés de aportar o ser no horizonte de uma integração pessoal, torna a pessoa vulnerável a cooptações por mecanismos de ideologização.

Exemplo dessa problemática é a deflagração que comumente orbita a palavra alienação. A maneira como ela recebe um significado mais atino à perspectiva do realismo socioeconômico da luta de classes parece ter-se deslindado radicalmente daquela sublime meta perseguida pelos místicos às voltas com a alienatio.

Acerca da acepção mais contemporânea, Staccone (1989, p. 116) fala em "essência opiácea da Religião" quando aborda a crítica marxista que a iguala à alienação: a religião "canaliza os protestos contra a ordem injusta da sociedade, rumo ao julgamento escatológico de Deus, conformando o homem em sua condição de vítima impotente" (STACCONE, 1989, p. 118).

As doutrinas religiosas seriam alienantes por suscitarem esperanças e expectativas para um horizonte supramundano, acarretando como efeito: a paralisação de possíveis mobilizações contra o estabelecimento da ordem injusta, o ocultamento das causas reais da exploração da força de trabalho e a legitimação da desigualdade social. 
Referindo-se também a essa discussão, Schüler (2002, p. 34) explica que Marx, já em 1844, nos "Manuscritos de Paris" (publicados somente em 1932), defendeu a "tese da raiz econômica de toda alienação": "Busca o conceito no idealismo germânico, mas trata de aplicá-lo às relações de produção. O operário produz riqueza que não lhe pertence, mas ao capitalista. É alienação. O homem trabalha, mas o produto do seu trabalho não satisfaz suas necessidades. Alienação. Esta alienação origina a propriedade privada".

Se adentrarmos melindrosamente na etimologia da palavra, veremos a perspectiva eminentemente religiosa de aliēnātǐō, -ōnis, que Ernesto Faria (1962, p. 59) apresenta no sentido próprio de "afastar" ou "distanciar". A separação ou ruptura, no aspecto da alienatio, tem vasta repercussão espiritual, distinta portanto da alienação ideológico-religiosa criticada por Marx, e chega a receber uma aplicação médico-psiquiátrica figurada, já que "perturbação" ou "delírio" são formas de separação, ruptura ou alienação da mente.

Um determinado trato com a palavra alienação pode ser equiparado com este estudo acerca da oração. Assim como no sentido ideológico-econômico da alienatio, uma prática de oração exaustivamente entregue à observância de cânones regimentares, não pode reportar ao ser nada do tributo devido ao controle institucional. Para adquirir valor ontológico, agora em consonância com o sentido espiritual de alienatio, é imprescindível à vida de oração não se imiscuir com apelos que remontam ao cenário de uma institucionalização.

Vamos estudar essa questão conhecendo a descrição dos tipos de oração para relacioná-los ao ser, na ordem de suas propriedades transcendentais. É indispensável antes verificar que as páginas do Catecismo contém abundante material para se pensar acerca de dois aspectos que principiam o ato de orar, pendendo ora para uma, ora para outra direção. São eles: se orar é dever ou espontaneidade.

No sentido da obrigação, a mensagem cristã estaria incisivamente constituída de exortações à oração. De três parábolas lucanas referenciais, duas convidam à oração intrépida e persistente (cf. CAT § 2613): a do amigo importuno - "Batei e [a porta] se vos abrirá" (cf. Lc 11,5-13) - e a da viúva importuna - "Mas, quando vier o Filho do homem, acaso encontrará fé na terra?” (cf. Lc 18,1-8). Essas passagens bíblicas têm o efeito 
de demonstrar, em certa escala, a participação de tradições na formação de uma Igreja crente e orante amparada contra um intelectualismo árido e espiritualmente infértil: "A oração não se reduz ao surgir espontâneo de um impulso interior; para rezar é preciso querer. Não basta saber o que as Escrituras revelam sobre a oração; também é indispensável aprender a rezar" (CAT § 2650).

Na perspectiva do "Catecismo", a oração, uma vez entendida como uma via inestimável na direção de tesouros espirituais exclusivos (cf. CAT $\S 2707$ aludindo à parábola do semeador em Mc 4,4-7.15-19), alcançaria requisitos para suplantar o limiar de uma modesta recomendação e receber o trato de uma carga metódico-pedagógica, pois “ao orar, Jesus já nos ensina a orar. [...] Como pedagogo, ele nos toma onde estamos e, progressivamente, nos conduz ao Pai. [...]. Enfim, falará abertamente do Pai e do Espírito Santo a seus discípulos, que deverão ser pedagogos da oração em sua Igreja" (CAT § 2607).

São veementes as interpelações de textos bíblicos para com uma concisa vida de oração (cf. CAT § 2599), condição necessária para aprofundar a união com Deus e até para proclamar o Evangelho (cf. CAT $\S 2600)$. Na doutrina do "Catecismo", o hábito da oração é indispensável para quem deseja ter uma visão contemplativa das coisas, tanto porque interiormente ela move a pessoa para o amor de Deus e do próximo (cf. CAT § 2601-2602).

Uma leitura como essa, que de alguma forma reconhece a oração num valor moral realçado, também acarreta a fixação dela ao plano do dever. Por conseguinte são obstruídas aquelas vias de espontaneidade onde o ato vem irrestritamente conjugado a uma moção interior, como atestam estas autorizadas palavras de Santa Teresa do Menino Jesus (apud CAT § 2607), também lembradas pelo Catecismo: "Para mim, a oração é um impulso do coração, é um simples olhar lançado ao céu, um grito de reconhecimento e amor no meio da provação ou no meio da alegria".

Essas palavras indicam uma vertente espiritualmente legítima, de contundente respaldo nestes versículos do apóstolo Paulo: "Ainda que não saibamos pedir como é devido, o próprio Espírito intercede por nós com gemidos inarticulados" ( $\mathrm{Rm} 8,26)$. Referindo-se à oração (= petição), 
temos: ao invés do imperativo, o ímpeto; antes que um dever, uma comoção; apartada da prescrição, um impulso.

Quando pressupõem inaptidão do homem, essas palavras podem ser usadas para justificar assistências rigidamente verticalizadas, onde a exigência da oração é custodiada por mecanismos coercitivos, e até mesmo vigiada, sob pena de punição, contra condutas consideradas execráveis. Por outro lado, é tendo em conta uma antropologia mais otimista que esse trecho concorre pelo despontar de uma libertação interior: a autêntica oração se legitima por um bem terapêutico, que efetua, no ser do orante, uma insuspeita transformação na organização de seu pensar e sentir. É isso o que Paulo redige com revestimento teológico: "o fruto do Espírito é amor, alegria, paz, paciência, amabilidade, bondade, fidelidade, modéstia, autodomínio. Contra isso não há lei" (Gl 5,22-23).

O Catecismo se põe a forjar um horizonte conciliador mediante variadas estratégias. Numa delas, ele se endereça ao foco de uma oração ininterrupta ou incessante: a oração atrelada às obras. "Oração e vida cristãs são inseparáveis, pois se trata do mesmo amor e da mesma renúncia que procede do amor" (CAT § 2745). O amor, em seu caráter operativo, é assim qualificado como uma oração efetiva, mostrando um íntimo estreitamento do desejo pessoal com as moções do Espírito Santo que "intercede" (CAT § 688) e é para os crentes o "mestre da oração" (CAT § 741). Isso faz parte da tradição evangélica (cf. Jo 15,16-17), como também se assinala em Orígenes (apud CAT § 2745): "Ora sem cessar aquele que une a oração às obras e as obras à oração. Somente dessa forma podemos considerar como realizável o princípio de orar sem cessar".

Outra estratégia se desenha com os recursos de um antigo adágio, desde que não se cometa o equívoco eulógico de confundir a natureza litúrgica da Igreja com o lamaçal disciplinar onde se atolam tantos carismas religiosos atualmente. Lex orandi, lex credendi - "a lei da oração é a lei da fé" (cf. CAT § 1124) - desvela prioritariamente um caráter eclesial eminentemente litúrgico: a Igreja é orante porque é essencialmente uma assembleia litúrgica (CAT § 2625), jamais por causa da proliferação de programas espúrios que reivindiquem algum semblante de religiosidade.

Diferentemente disso, as palavras de João Paulo II (1981, n. 44) expõem a necessidade histórica de um valor segundo o qual quem ora deve crer e quem 
crê deve orar: "É na prática da sua oração que a Igreja exprime principalmente a sua fé, de modo que 'a regra da oração fixou a regra da fé'. Por isso é preciso conservar fielmente a lex orandi para evitar que se coloque em perigo a lex credendi”.

Seja por conta de sua própria formulação, ou de uma leitura demasiado tendenciosa (a-litúrgica), essa máxima perpetra em nossos dias uma associação aparentemente indestrutível entre a virtude de orar e o dever moral e disciplinar para com a oração. Desejamos refletir que, sob um ponto de vista ontológico, a gratuidade e o dever de oração constituem perspectivas discrepantes e não podem se conciliar. Em vista de algum benefício para um homem anelante de verdadeira transformação interior, o autêntico caminho de oração é o que se dá pela via dos princípios transcendentais do ser.

\section{Correlação entre os tipos de oração e os transcendentais}

A tomar pelo episódio da expulsão dos vendilhões, a oração tem centralidade na mensagem de Jesus, vindo a polarizar o Templo-instituição como: ou casa de oração, ou covil de ladrões (Mt 21,13). Mantém-se cen-

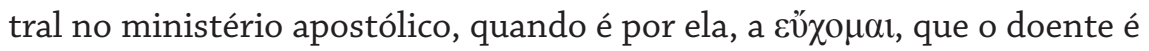
salvo (Tg 5,15) (MOURA, 1998, p. 165).

Temos nos encaminhado a afirmar que, se gerida por observância regimentar, a prática da oração incorre em inautenticidade: presta-se a satisfazer um procedimento institucional qualquer, deixando de haurir todos os recursos próprios de sua especial vinculação ao ser.

A indagação crítica que levantamos é esta: ao orar, o fiel se move pela imposição do preceito ou pela escuta do ser? Avaliaremos essa questão dialogando com um documento catequético oficial da Igreja Católica e consultando a autoridade patrística agostiniana, ao passo dos comentários de Jolivet acerca dos transcendentais.

\section{0 louvor e o ser em si}

Antes de falarmos das propriedades do ser, é preciso nos remetermos ao próprio ser. Segundo Jolivet (1982, p. 268), os transcendentais coincidem 
ou se identificam realmente com o ser que é transcendental, são convertíveis com o ser, o determinando a partir de dentro e, jamais lhe acrescentando uma diferença extrínseca. A unidade, a verdade e o bem portanto não acrescentam nada de real ao ser, pois o ser necessariamente os contém; eles não fazem mais do que esclarecer os diferentes aspectos do ser.

Urge assim, preliminarmente, trabalhar a ideia mesma de transcendental. Algumas demarcações iniciais surgem dessa análise. Primeiramente, chama-se transcendental em razão de transcender ou ultrapassar o nível das categorias. Em seguida, a noção de ser se aplica a tudo o que é ou pode ser, de qualquer forma que seja. Isso se dá, para Jolivet (1982, p. 267), pela sua mais alta generalidade ou porque o ser não é um gênero.

A definição de louvor nos parece a mais consonante com a noção de transcendental, pois a oração de louvor alinha o orante ao ser em si mesmo, quer dizer, à transcendência do ser: é o louvor "a forma de oração que reconhece o mais imediatamente possível que Deus é Deus! Canta-o pelo que Ele mesmo é, dá-lhe glória, mais do que pelo que Ele faz, por aquilo que Ele É" (CAT § 2639).

Essa correspondência com o transcendental abre um novo horizonte de significação para o louvor, ao menos em comparação com algumas acepções mais comuns. Geraldo de Moura (1998, p. 146) as sintetiza: louvar é "celebrar, cantar hinos, salmos, engrandecer, proclamar", laudar e bendizer. Mas, distintamente, a tratá-lo nesse nível, para o Catecismo, "o louvor integra as outras formas de oração e as leva Àquele que é sua fonte e termo final: 'O único Deus, o Pai, de quem tudo procede e para quem nós somos feitos' (1Cor 8,6)” (CAT § 2639).

A compreensão do louvor como a síntese integradora das demais formas de oração no aspecto da totalidade do ser se adequa ao ensino de Jolivet (1982, p. 269), segundo o qual, considerando-o em si, absolutamente, "nada se pode dizer dele senão que o ser é". A sintonia com o ser, mais do que tratar o louvor como júbilo e exultação, torna-o equiparado a certa apreensão intuitiva da ordem do mundo. Isso pode se apresentar, filosoficamente, como generalidade, ou num sentido mais religioso, se desdobrar justamente em louvor. Um claro exemplo é elaborado por Santo Agostinho em seu diálogo "A ordem": 
Seguir e perceber a ordem das coisas, caro Zenóbio, a que se refere a cada uma em particular, e ainda mais ver e explicar a ordem do universo, que guia e governa o mundo, é muitíssimo difícil e raro para os homens. Acrescente-se a isso o fato de que, embora alguém o possa fazer, não consegue encontrar um ouvinte que, quer pelo mérito de sua vida, quer por certa situação de conhecimentos, seja digno de coisas tão divinas e tão obscuras (AGOSTINHO, De ordine I, 1).

As dificuldades de definição de um conceito são maiores quanto maior for sua generalidade: isso articula um consenso de se apreciar o silêncio como a meta da oração de louvor. Sem o acréscimo de predicativos, quiçá em seu aspecto mais genuíno, a forma do louvor comporta um número bastante reduzido de palavras: desprende-se de confabulações e palavrórios e, por conseguinte, aproxima-se do êxtase em função do liame da inefabilidade: "Se o compreendesses, ele não seria Deus", escreve Santo Agostinho (apud CAT § 230) no "Sermão 52".

Essas indicações sugerem uma cautela redobrada contra a identificação da mística a sensações de unificação com o todo cósmico, pois o louvor aponta para o Ser que, inexprimível, não admite confundir-se com experiências opacas. Contrariando essa tendência, uma antiga formulação agostiniana em "A vida feliz" convalida a coordenada ontológica, concluindo que é feliz só quem "possui" a Deus: "se alguém quiser ser feliz, deverá procurar um bem permanente, que não lhe possa ser retirado em algum revés de sorte. [...] Logo, quem possui a Deus é feliz!" (AGOSTINHO, De beata vita II,11).

\section{A ação de graças e a bondade (bonitas)}

Aparentemente, a oração de agradecimento recebe do Catecismo uma abordagem modesta e quase indireta. Contudo a ação de graças é ricamente entendida como predicativo de outra ação: a oferenda. Lê-se esta frase: "Como na oração de súplica, todo acontecimento e toda necessidade podem se tornar oferenda de ação de graças [cf. 1Ts 5, 18]" (CAT § 2638).

Elementarmente, agradecer consiste em ter gratidão, no sentido carismático ( $\chi \alpha \dot{\rho} \rho v$ Ě $\chi \omega)$ de Lc 17,9, e “dar graças”, no sentido eucarístico 


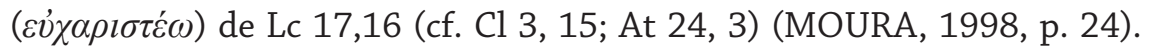
É desse último aspecto que emana a impreterível condição de uma oferenda, que no Novo Testamento jamais se concretiza sem um efetivo oferecer, seja em quaisquer de suas múltiplas concreções, como: "levar ao alto" (At 7,41) ou um "apresentar" (Lc 24,42), uma "libação" (2Tm 4,6), "dom" (Lc 21,5) ou "oblação" (At 24,17) (MOURA, 1998, p. 163).

Agradecer é oferecer; oferecer consiste, por sua vez, num ato oblativo. Por um raciocínio direto, chegaríamos à gratidão como a forma de oração que melhor se associa à bondade: precisamente, o atributo que se desvela da relação do ser com a vontade (JOLIVET, 1982, p. 269).

Em suas lições, Jolivet (1982, p. 271) também afirma que "a bondade exprime de princípio uma relação com uma tendência: o ser é bom enquanto pode atender a uma necessidade ou aplacar um desejo" (grifo nosso). O bom é a propriedade transcendental do ser que fundamenta a ação de graças numa ação voluntariosa: se há vontade, há o desejo que prepara o oferecimento de si; se o desejo é saciado pela gratuita bondade do ser, é gerada a gratidão.

Por conseguinte a ação de graças mais autêntica é aquela que está associada integralmente mais a uma moção volitiva do que a um dado de consciência: a gratidão nasce do ímpeto da vontade, jamais adquirindo a mesma força se partindo de um argumento persuasivo ou por razões de conviç̧ão.

Isso é visto com muita evidência nesta admoestação de Santo Agostinho no "Comentário da Primeira Epístola de São João", ao tratar do desejo do coração: "O bem deve encher tua alma. Joga fora o mal. Supõe que Deus quer te encher de mel. Se estás cheio de vinagre, onde pôr o mel? Será preciso esvaziar o conteúdo do jarro. Limpar bem o próprio vaso" (AGOSTINHO, In epistolam Ioannis ad Parthos IV,6). A analogia com o mel e o vinagre destaca que o bem, de que a alma é tomada pela oração, é o próprio exercício de ser bondoso, a bondade traduzida em ações, não havendo como lhe preterir a vontade de praticá-las.

\section{A adoração e a verdade (veritas)}

De acordo com a doutrina de Jolivet (1982, p. 269), relacionando, desta vez, com a inteligência, descobre-se que o ser é verdadeiro. A verdade, 
nessa perspectiva, é aquilo que é próprio do ser enquanto abordável pelo conhecimento e sujeito a uma inteligibilidade (JOLIVET, 1982, p. 271).

Para demonstrarmos a afinidade de algum tipo de oração com esse transcendental, sondamos os requisitos que, em matéria intelectiva, são preenchidos principalmente pela adoração. Dentre as acepções neotesta-

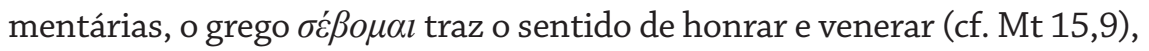

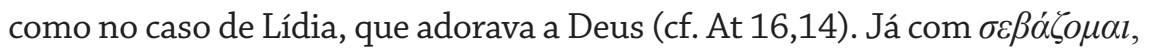
fala-se dos pagãos que cultuaram e serviram a criatura em lugar do criador (cf. Rm 1,25). Tanto para a visita dos magos (cf. Mt 2,2) como para a iminência dos verdadeiros adoradores (cf. Jo 4,23) está o verbo $\pi \rho o \sigma \kappa v v \varepsilon ́ \omega$, significando prostrar, fazer reverência (MOURA, 1998, p. 22).

O Catecismo justapõe a adoração com a bênção: esta, exprimindo o movimento de fundo da oração cristã (cf. CAT § 2626); aquela, sendo a "primeira atitude do homem que se reconhece criatura diante de seu Criador" (CAT § 2628).

O dado bíblico se revela encaminhando-se para uma nova adoração, possibilitada pela obtenção de um novo conhecimento: "Vós prestais culto ao que desconheceis, nós damos culto ao que conhecemos; [...] Mas chega a hora, e já chegou, em que os que prestam culto autêntico prestarão culto ao Pai em espírito e de verdade. Tal é o culto que o Pai procura" (Jo 4,22-23).

O testemunho de Santo Agostinho nas Confissões segue a mesma direção dessa correspondência onde a adoração é a forma de oração que se coaduna com a verdade transcendental:

Examinei minhas fraquezas pecaminosas sob as três formas de concupiscência, e invoquei tua destra para me salvar. Apesar de ter o coração ferido, vi o teu esplendor e, ofuscado, falei: Quem pode lá chegar? Sim, fui expulso da tua presença. Tu és a verdade que a tudo preside, e eu, na minha avidez, não queria perder-te, mas possuir a ti e ao mesmo tempo a falsidade. Pois, ninguém quer mentir tanto, a ponto de ele mesmo ignorar a verdade. E assim te perdi, porque tu não aceitas ser possuído juntamente com a mentira (AGOSTINHO, Confessiones X, 41, 66).

Esse texto agostiniano demonstra que a adoração prestada a Deus se funda num conhecimento da verdade. Não seria adoração se não houvesse esse pressuposto. 
Não é coincidência que a primeira página das Confissões, com várias citações sálmicas (Sl 47/48, 2; 95/96, 4; 144/145, 3; 146/147, 5), tenha sido aberta com uma adoração. Santo Agostinho esboça uma explícita intenção de louvar a Deus; porém o louvor, que consiste em reconhecer a Deus como Ele é, não seria autêntico se não se pautasse na adoração, pela qual o homem se apercebe da verdade de sua própria condição.

"Grande és tu, Senhor, e sumamente louvável: grande a tua força, e a tua sabedoria não tem limite". E quer louvar-te o homem, esta parcela de tua criação; o homem carregado com sua condição mortal, carregado com o testemunho de seu pecado e com o testemunho de que resistes aos soberbos [cf. 2Cor 4, 10; Rm 7, 17.23]; e, mesmo assim, quer louvar-te o homem, esta parcela de tua criação. Tu o incitas para que sinta prazer em louvar-te; fizeste-nos para ti, e inquieto está o nosso coração, enquanto não repousa em ti. Dá-me, Senhor, saber e compreender qual seja o primeiro: invocar-te ou louvar-te; conhecer-te ou invocar-te (AGOSTINHO, Confessionum I, 1, 1).

Sob o risco de não ser verdadeiro, o louvor, como vemos na postura agostiniana, não pode prescindir da adoração. Essa prerrogativa também se expressaria antropologicamente do seguinte modo: se a Deus se louva pelo reconhecimento do Ser divino que Ele é, não se pode adorá-lo, em contrapartida, sem o reconhecimento do ser (do) humano. Se o louvor se faz pela verdade de quem é Deus, a adoração se condiciona à verdade de quem é o homem, a saber: criatura, pecador e mortal, um "mendigo de Deus [Sto. Agostinho, Serm. 56, 6, 9]” (apud CAT §2559).

Todavia, a pessoa não se reconhecerá assim se não for mediante a humildade. Nesse sentido, o Catecismo ensina que "a humildade é o fundamento da oração" (CAT §2559), pois quem se humilha será exaltado (cf. Lc 18,9-14), ou seja: terá sua alma elevada a Deus por meio da oração.

A humildade avaliza uma oração verdadeira prescrevendo, com isso, a adoração, que o Catecismo define também nos seguintes termos: “É prosternação do Espírito diante do 'Rei da glória' [cf. Sl 24,9-10] e o silêncio respeitoso diante do Deus 'sempre maior' [Sto. Agostinho, En. in Psal. 62,16]" (CAT §2628). Como condição de verdade da oração, é a humildade que se coaduna invariavelmente ao espírito de adoração. 


\section{A petição e a unidade ( unitas)}

Seguindo com Jolivet (1982, p. 269), o uno é o atributo que assinala, desde um ponto de vista negativo, a indivisibilidade do ser: o ser é uno porque não pode ser divisível. Acreditamos que esse enunciado convém à oração de pedido, desde que entendida numa dimensão ontológica.

A noção de unidade carrega consigo o tema da composição dos seres que, sem suas partes, inevitavelmente não existiriam. Todo ser é uno por essência. No entanto sua unidade pode ser compreendida ou pela simplicidade - a unidade do ser que não tem partes, ou seja, o Ser divino — ou pela composição - a unidade do ser enquanto suas partes estão reunidas e constituindo o próprio composto (JOLIVET, 1982, p. 270).

Essa compreensão reverbera por variados assuntos. Por exemplo: a morte é no Catecismo pensada exatamente como a dissolução do composto humano, tal como ensinavam os Padres da Igreja: "Pela unidade da natureza divina, que permanece presente em cada uma das duas partes do homem, estas se unem novamente. Assim, a Morte se produz pela separação do composto humano, e a Ressurreição, pela união das duas partes separadas [S. Gregório de Nissa]" (CAT § 650).

Corpo e alma, porém, não formam no ser humano apenas uma unidade: esta é tão profunda "que se deve considerar a alma como a 'forma' do corpo; ou seja, é graças à alma espiritual que o corpo constituído de matéria é um corpo humano e vivo" (CAT § 365). Essa antropologia, sem dúvida, enriquece a apreciação da criatura humana como um ser, ao mesmo tempo em que desvenda mais acuradamente a tragédia do pecado. $\mathrm{O}$ Catecismo discorre sobre isso nesta transcrição:

"Instigado pelo Maligno, desde o início da história o homem abusou da própria liberdade" [GS 13/1]. Sucumbiu à tentação e praticou o mal. Conserva o desejo do bem, mas sua natureza traz a ferida do pecado original. Tornou-se inclinado ao mal e sujeito ao erro:

"O homem está dividido em si mesmo. Por esta razão, toda a vida humana, individual e coletiva, apresenta-se como uma luta dramática entre o bem e o mal, entre a luz e as trevas" [GS 13/2] (CAT § 1707). 
O pecado não só instaurou uma ambivalência na natureza do homem, como também no seio da humanidade, vindo a repercutir drasticamente inclusive no âmbito das relações conjugais (CAT § 1607). "Todos os homens estão implicados no pecado de Adão. São Paulo o afirma: 'Pela desobediência de um só homem, todos se tornaram pecadores' (Rm 5,19)” (CAT § 402).

Essas considerações catequéticas deixam notar que a petição não comporta apenas um pedido, enquanto se mostrar patente o estado de penúria daquele que pede. Tal estado pode ser expresso ontologicamente pelo desmantelamento do ser, ou moralmente, por sua depravação, ou ainda espiritualmente, como dispersão. Escreve Santo Agostinho:

Eis que habitavas dentro de mim e eu te procurava do lado de fora! Eu, disforme, lançava-me sobre as belas formas das tuas criaturas. Estavas comigo, mas eu não estava contigo. Retinham-me longe de ti as tuas criaturas, que não existiriam se em ti não existissem. Tu me chamaste, e teu grito rompeu a minha surdez. Fulguraste e brilhaste e tua luz afugentou a minha cegueira. Espargiste tua fragrância e, respirando-a, suspirei por ti. Eu te saboreei, e agora tenho fome e sede de ti. Tu me tocaste, e agora estou ardendo no desejo de tua paz (AGOSTINHO, Confissões X, 27, 38).

No pedido transparece, assim, a condição de necessidade do pedinte. De maneira mais ordinária e atenuada com o verbo aiıź $\omega$, Mc 15,6 exprime o desejo da multidão por Pilatos seguir o costume de na páscoa soltar um prisioneiro (MOURA, 1998, p. 170). Já enquanto súplica, a pe-

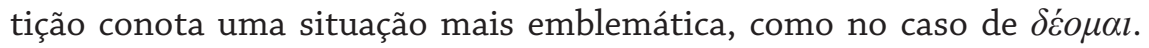
Em Lc 9,38, consiste no rogo do pai que grita da multidão pela vida de seu filho único (MOURA, 1998, p. 210); em Lc 1,13, na súplica (atendida) de Zacarias por um herdeiro (MOURA, 1998, p. 165); já em Lc 8,28, trata-se dos demônios do geraseno implorando que Jesus não os atormente; e em Lc 22,32, é o próprio Jesus rogando a Simão Pedro que vença a prova lhe preparada por Satanás (MOURA, 1998, p. 170).

Desde a perspectiva de relação com a unidade transcendental, toda súplica há de se abstrair de problemas efêmeros e triviais para alçar um vigoroso contraponto à dissolução. A oração de pedido incendeia um desejo não só de conversão, como também de unificação interior: por isso sua relação com o uno. 
Enquanto a condição humana vem desterrada na desolação, insegurança e solidão, a mais sábia e conveniente das orações, aconselha Agostinho na Carta a Proba, é pedir a vida bem-aventurada: "ora beatam vitam" (AGOSTINHO, Epistola 130, 4, 9).

Mediante a petição ou a súplica, chama-se a Deus com insistência, invocando-o, bradando, gritando e até reclamando. Quaisquer sejam os matizes de vocabulário, essa forma de oração traduz a consciência da nossa relação com Deus, segundo o Catecismo: "como criaturas, não somos nem nossa origem, nem senhores das adversidades, nem nosso fim último. Mas, como pecadores sabemos, na qualidade de cristãos, que nos afastamos de nosso Pai. O pedido já é uma volta para Ele" (CAT § 2629): pelo gemido (cf. Rm 8,22-24), pelo pedido de perdão (cf. Lc 18,13), pelo desejo centrado na busca do Reino (cf. Mt 6,10.33; Lc 11,2.13) ou em qualquer necessidade (cf. Tg 1,5-8; Ef 5,20).

Convém sublinhar que a oração de cura possui notável afinidade com a petição, pois todo desejo de cura, que se exprime pela oração para alcançá-la, passa pelas condições de uma súplica (e, não tardiamente, pela intercessão). A íntima relação entre a petição e a unidade (bem como a intercessão com a beleza, como veremos a seguir), ressaltaria para todo desejo de cura um valor e significado que se somariam àqueles mencionados pela Congregação para a Doutrina da Fé na Instrução sobre as orações para alcançar de Deus a cura (cf. n. 1). Toda cura tende a ser algo que perfaz o lastro da unidade e beleza eclesiais.

\section{A intercessão e a beleza (pulchritudo)}

A intercessão é tida pelo Catecismo como uma especificidade das orações de súplica e petição. Sua peculiaridade está na mudança do objeto, qual rogo que se faz pelo outro, não por si mesmo: "Na intercessão, aquele que ora não 'procura seus próprios interesses, mas pensa sobretudo nos dos outros' (Fl 2,4) e reza mesmo por aqueles que lhe fazem mal [cf. At 7, 60; Lc 23,28.34]" (CAT § 2635).

Foi uma forma de partilha intensamente vivida pelas primeiras comunidades cristãs (cf. CAT § 2636), vindo a ser indispensável para fazer 
valer o amor universal e incondicional (cf. Mt 5,44). Está na base da autocompreensão da Igreja como "comunhão dos santos" (cf. CAT § 2635), pois "a intercessão dos cristãos não conhece fronteiras: 'Por todos os homens, pelos que detêm a autoridade' (1Tm 2,1$)$, pelos que nos perseguem [cf. Rm 12,14], pela salvação daqueles que recusam o Evangelho [cf. Rm 10,1]" (CAT § 2636).

Essa explicitação universalista da intercessão serve de primeiro vestígio para articulá-la com uma propriedade transcendental do ser. O belo é por vezes apresentado não como um transcendental a mais, e sim o agrado resultante da conjunção de tudo: é o "esplendor dos transcendentais reunidos” (FORTE, 2006, p. 34-35), a atração gerada pela conjunção da verdade, unidade e bem. Tais características são evocadas por Santo Tomás de Aquino em sua definição id quod visum placet, recapitulada por Jolivet (1982, p. 338): belo é o que agrada ver.

A visibilidade (visum) apalpa a natureza do conhecimento intuitivo: é necessário que a beleza resulte de condições acessíveis à inteligência; logo, o belo se conjuga ao verdadeiro. É também fonte de satisfação (placet), por ser deleitável, aprazível, encantador, arrebatador, gerando desejo, inclusive amor: vincula-se portanto à bondade (JOLIVET, 1982, p. 338-339).

No que concerne à unidade, é facilmente notável como a beleza coopera com esse transcendental. Como o belo atrai, é-lhe intrínseca a produção de congraçamentos, um efeito aliás absolutamente visado por toda atitude intercessora.

Não seria imprevisível que o belo, versátil em se compor nas demais propriedades, pudesse ser concebido por meio da própria noção de transcendental, como acima vimos associada ao louvor. Por isso nestas palavras de Santo Agostinho (apud CAT § 33) no "Sermão 241" não encontraríamos outro transcendental a não ser o belo:

Interroga a beleza da terra, interroga a beleza do mar, interroga a beleza do ar que se dilata e se difunde, interroga a beleza do céu [...] interroga todas estas realidades. Todas elas te respondem: olha-nos, somos belas. Sua beleza é um hino de louvor (confessio). Essas belezas sujeitas à mudança, quem as fez senão o Belo (Pulcher, pronuncie "púlquer"), não sujeito à mudança? 
Relacionada aos transcendentais, a beleza não se reduz a efeitos estéticos; quanto mais à oração, sobre cujas fórmulas recaem um rigoroso critério terminológico. Mas nada obsta que fórmulas teologicamente certas sejam, quando rezadas, mais flexivelmente vestidas de maneira digna, nobre e bela, em se tratando de um traço refletido na criatura da parte do Criador: pois "o mediador entre Deus e os homens devia ter alguma semelhança com Deus e alguma semelhança com os homens" (AGOSTINHO, Confissões X, 42, 67).

É por essa característica salientemente plástica, adaptável e flexível que relacionamos a intercessão ao belo transcendental. O mesmo Santo Agostinho (apud CAT $\S 2616$ ), em seu Comentário ao Salmo 85, concebe um primoroso desdobramento da intercessão, vista desta vez sob o nome de mediação: "Ele [Jesus] ora por nós como nosso sacerdote, ora em nós como nossa cabeça, e a Ele sobe nossa oração como ao nosso Deus. Reconheçamos pois, nele, os nossos clamores e em nós os seus clamores". Essa semelhança promovida pela mediação só pode conduzir ao belo: "nossa alma [...] era feia devido ao pecado. Amando a Deus, torna-se bela" (AGOSTINHO, In epistolam Ioannis ad Parthos IX, 9).

\section{Considerações finais}

Quando averiguamos um possível desalojamento da oração de quadros normativos a fim de ser reimplantada num curso mais existencial e autônomo, atendemos à convicção de que o apelo à oração seja de cunho ontológico, não podendo ser lícito sobrepor-lhe qualquer norma disciplinar em circunstância nenhuma. Nós emitimos esse parecer, potencialmente estrondoso para as escolas de Teologia Espiritual e Ascética, como consequência da aproximação com a Ontologia.

No ambiente dos ordenamentos religiosos, a fidelidade à oração cotidiana, assumida como uma necessidade fundamental, assim como o ritmo estável e previsto de oração pessoal e comunitária, não representam fonte alguma de autenticidade espiritual caso se deem por coordenadas completamente diversas à dinâmica entre as formas de oração e as propriedades transcendentais do ser. 
O que se deve sublinhar como normativo são os gêneros de oração, estes também sujeitos às oscilações do coração humano. A vinculação ao desejo, fato que evidencia a preeminência do amor, constitui uma via existencial e antropológica para a vida de oração, absolutamente alheia aos cânones regimentares.

Uma promissora interação entre Teologia Espiritual e Ontologia é o pré-requisito de uma via argumentativa para indexar à liceidade o valor infinitamente mais sublime da autenticidade: pois diz do amor a Deus com todo o entendimento e todas as forças (cf. Mc 12,30). Explore-se nisso uma oportuna catequese a fim de que se ensine, para cada tipo de oração, um sentido endereçado ao logos, não ao nomos.

Sob a copa de um mesmo termo há formas variantes em estilo, necessidade e intenção. Uma "oração", independentemente da solenidade, molda-se de tal maneira aos anseios da pessoa humana, que se torna um fenômeno naturalmente recorrente no campo das expressões comunicativas. A sensibilidade para esse comportamento tipicamente elástico da oração preceitua uma correspondência com o unum, o verum e o bonum. As definições que provêm dessa relação fornecem a apreciação do tema investigado neste artigo.

De um olhar para as formas de oração conjugadas às propriedades transcendentais do ser, resultaria a nota do louvor como a que mais se compactua ao silêncio, à mística ou à contemplação, suplantando o limiar da linguagem e contrariando sua vinculação a ambientes de revivescência ou aclamações em série. Certa novidade também estaria veiculada no conceito de adoração estreitado à sapiência: essa forma de oração, tão prezada pela virtude de religião para a instituição de rituais litúrgicos e o culto do único e verdadeiro Deus, não subsistiria sem uma busca sincera de autoconhecimento por parte do orante: o que este reconhece da verdade de si mesmo determina a verdade de seu ato de adoração a Deus.

As propriedades transcendentais da unidade e da bondade têm seus correlatos nas orações de súplica e agradecimento, respectivamente. É praticamente imperioso que a gratidão, uma iniciativa de força volitiva, seja precedida pela petição, cuja porta restitui ao homem a cura de uma vontade reta, não mais atordoada pelo ímpeto das paixões desordenadas. 
Sugerimos, por fim, que o dom da concórdia ou a arte da reconciliação, sendo afins à intercessão, sejam privilegiadamente engatilhados para um viés não necessariamente ético (em vista do bem), mas efetivamente estético (em vista do belo que congraça o bem).

Todos esses focos são reclamados desde o instante em que a Filosofia orquestra uma doutrina sobre os transcendentais, que irá impactar diretamente na maneira como a Teologia subsidiará uma compreensão sobre a oração e a vida espiritual, mais em sintonia com o apelo do ser do que com táticas de controle institucional.

\section{Referências}

AgOstinho DE HIPONA. A ordem. Tradução de Agustinho Belmonte. São Paulo: Paulus, 2008. (Patrística, 24).

AGOSTINHO DE HIPONA. A vida feliz. Tradução de Nair de Assis Oliveira. São Paulo: Paulus, 1998. (Patrística, 11).

AGOSTINHO DE HIPONA. Carta 130 a Proba. Tradução de Nair de Assis Oliveira. São Paulo: Paulinas, 1987. (Espiritualidade).

AGOSTINHO DE HIPONA. Comentário da Primeira Epístola de São João. Tradução de Nair de Assis Oliveira. São Paulo: Paulinas, 1989. (Espiritualidade).

AgOstinho DE HIPONA. Confissões. Tradução de Maria Luiza Jardim Amarante. São Paulo: Paulus, 1997. (Patrística, 10).

BÍBLIA. Grego-Português. Novo Testamento interlinear grego-português. Tradução de Vilson Scholz. Barueri: Sociedade Bíblica do Brasil, 2004.

BÍBLIA. Português. Bíblia do peregrino. SCHÖKEL, L. A. (Coord.). 3. ed. Tradução de Ivo Storniolo e José Bortolini. São Paulo: Paulus, 2011.

CATECISMO DA IGREJA CATÓLICA [CAT]. 9ª ed. Petrópolis: Vozes; São Paulo: Loyola; Paulinas; Ave-Maria; Paulus, 1999.

CONGREGAÇÃO PARA A DOUTRINA DA FÉ. Instrução sobre as orações para alcançar de Deus a cura. São Paulo: Paulinas, 2000. 
FARIA, E. (Org.). Dicionário escolar latino-português. 3. ed. Rio de Janeiro: Companhia Nacional de Material de Ensino (C.N.M.E.), 1962.

FORTE, B. A porta da beleza: por uma estética teológica. São Paulo: Idéias \& Letras, 2006.

JOÃO PAULO II. Instrução sobre a formação litúrgica nos seminários. $2^{\mathrm{a}}$ ed. São Paulo: Paulinas, 1981. (A voz do Papa, 95).

JOLIVET, R. Curso de Filosofia. 14. ed. Rio de Janeiro: Livraria Agir, 1982.

MOURA, G. de. Dicionário do Novo Testamento em português-grego-latim. Vitória: EDUFES, 1998.

SCHÜLER, A. Dicionário enciclopédico de Teologia. Canoas: ULBRA, 2002.

STACCONE, G. Filosofia da Religião: o pensamento do homem ocidental e o problema de Deus. Petrópolis: Vozes, 1989.

TANQUEREY, A. Compêndio de Teologia Ascética e Mística. 5. ed. Porto, Portugal: Apostolado da Imprensa, 1955 [1928].

Recebido: 06/11/2015

Received: 11/16/2015

Aprovado: 20/05/2016 Approved: 05/20/2016 